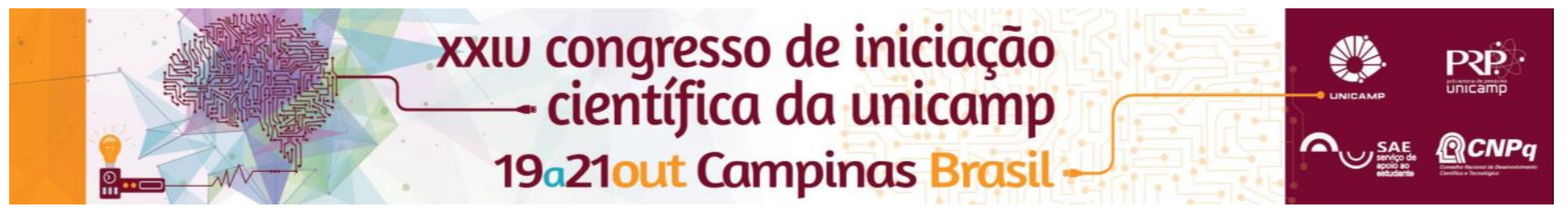

\title{
Destinos ambientalmente adequados dos resíduos da construção civil
}

\author{
Tauane Evelis Brito Souza (IC); Luísa Andréia Gachet Barbosa(PG)
}

\section{Resumo}

Atualmente existe um grande volume de desperdícios nas obras da construção civil, com essa geração de resíduos sólidos a extração de matéria-prima e o descartes inadequados também é um problema, tendo como solução a reciclagem dos entulho, assim tem-se uma redução da poluição, do consumo de energia da extração de matérias-primas, da quantidade de resíduos, das disposições de entulho em áreas irregulares, e consequentemente tem-se uma melhoria na qualidade de vida urbana. Uma atitude da prefeitura de Limeira foi a instalação de 11 ecopontos na cidade, além de colaborar para a preservação da natureza ao substituir a extração da matéria-prima por material reciclável, tem-se o destinos adequados dos materiais.

Palavras-chave: Resíduos Solídos; Reciclagem; Ecopontos;

\section{Introdução}

A construção civil gera resíduos em toda a sua vida, desde a implantação da obra até a demolição dessa, precisa-se ter um controle para diminuir ou eliminar a quantidade de perdas em algumas fases da construção, para que haja uma melhora significativa.

A resolução 448 do CONAMA de 2012 prevê que os gerados deverão ter como objetivo prioritário a não geração de resíduos e, secundariamente, a redução, a reutilização, o tratamento dos resíduos sólidos e a disposição final ambientalmente adequada dos rejeitos. Os Planos de Gerenciamento de Resíduos da Construção Civil, de empreendimentos e atividades não enquadrados na legislação como objeto de licenciamento ambiental, deverão ser apresentados juntamente com o projeto do empreendimento para análise pelo órgão competente do poder público municipal, em conformidade com o Plano Municipal de Gestão de Resíduos da Construção Civil.

Uma forma de minimizar os impactos é a instalação de ecopontos pela cidade, possibilitando que quaisquer pequenos geradores de resíduos possam utilizar, os ecopontos são áreas disponibilizadas pela prefeitura para que haja a triagem dos resíduos recebidos (aceitando qualquer tipo de resíduos, menos os orgânicos), são implementados e operados pelo órgão público responsável. $\mathrm{Na}$ cidade de Limeira atualmente possui um total de 11 ecopontos em funcionamento.

\section{Resultados e Discussão}

Durante a pesquisa, foram elaborados questionários específicos para auxiliar no levantamento de informações dos ecopontos visitados. Foi possível aplicar o questionário nos seguintes ecopontos: Jd Anavec, Pq. Nossa Senhora das Dores e Belinha Ometto (Figura 1, 2, 3 e 4).

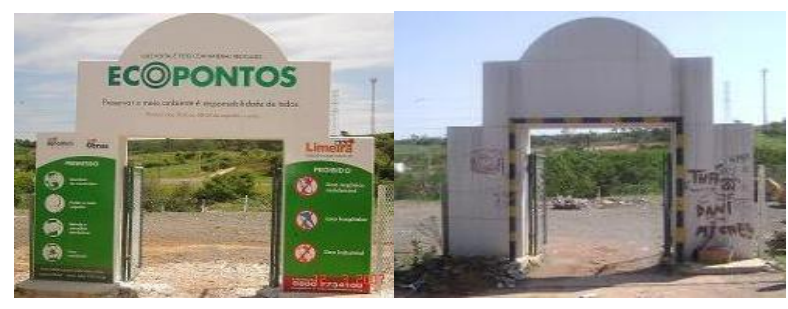

Figura 1: O antes e depois da fachada do ecoponto do Jardim Anavec
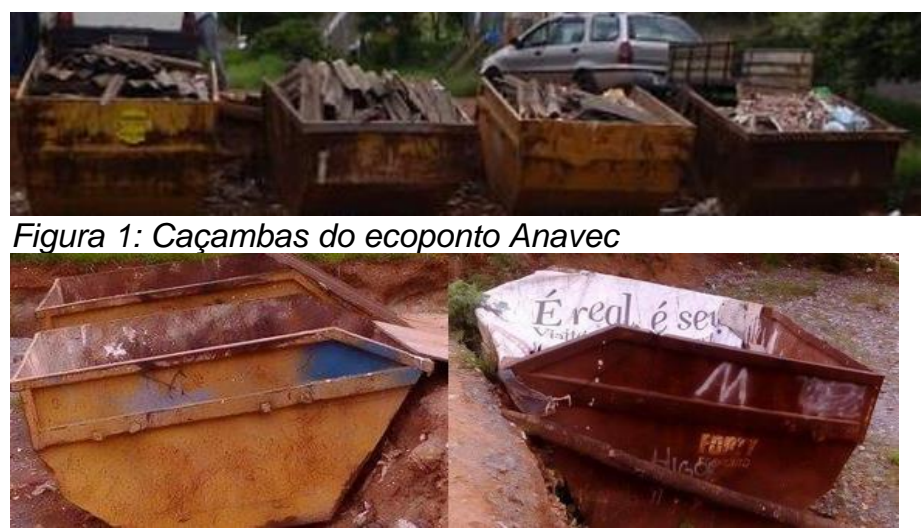

Figura 2: Caçambas do ecoponto Nossa Senhora das Dores

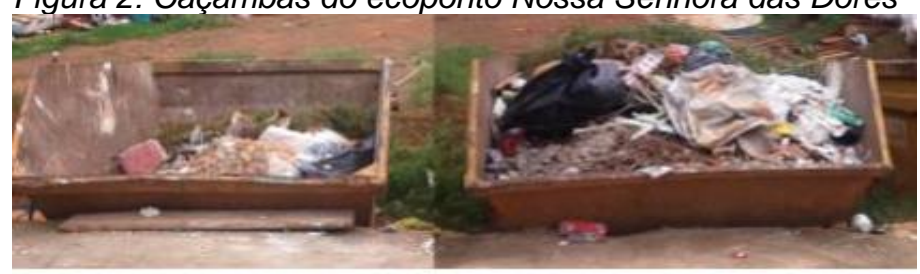

Figura 3: Caçambas do ecoponto Belinha Ometto

Também se elaborou um questionário para as empresas de caçambas. Foi possível aplica-lo na Empresa "Cardoso Tira Entulho".

\section{Conclusões}

Com base nas pesquisas realizadas, pode-se observar que os resíduos sólidos ainda não têm o destino final correto, é preciso que a população (tanto grande e pequenos gerados) tenha consciência para levar os entulhos para os locais corretos.

\section{Agradecimentos}

Agradeço a Faculdade de Tecnologia, ao CNPQ, a professora Dra Luísa Andréia Gachet Barbosa.

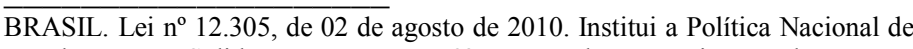
Resíduos Sólidos. $\quad-\quad 2^{\mathrm{a}}$ Ed. http://bd.camara.leg.br/bd/handle/bdcamara/14826 - Brasília, 2012

CONAMA - Conselho Nacional do Meio Ambiente (2012). Resolução No 448, de

18 de janeiro de 2012. Publicada no Diário Oficial da União (DOU) em $19 / 01 / 2012$.

SANTOS, I. R. - Medidas para a redução dos impactos ambientais gerados pela construção civil (Março de 2015) Projeto de Graduação. Disponível em http://monografias.poli.ufrj.br/monografias/monopoli10014319.pdf. 